\title{
The Effect of Using Different Levels from Date Palm Pollen in Diet on Productive Performance and Some Eggs Quality Measurements for Layer Hens Lohman
}

\author{
Ammar Qahtan Shanoon, Mahdi Salih Jassim, Ali Hossen Mohamed, Mohamed Saleh Latef, \\ Ali Mohamed Abad AL-Raheem
}

Dept. of Animal Resources, College of Agriculture, University of Diyala, Baquba, Iraq

Email address:

drammarshanoon@gmaill.com (A. Q. Shanoon)

\section{To cite this article:}

Ammar Qahtan Shanoon, Mahdi Salih Jassim, Ali Hossen Mohamed, Mohamed Saleh Latef, Ali Mohamed Abad AL-Raheem. The Effect of Using Different Levels from Date Palm Pollen in Diet on Productive Performance and Some Eggs Quality Measurements for Layer Hens Lohman. Animal and Veterinary Sciences. Special Issue: Recent Trends in Animal Production and Healthcare. Vol. 3, No. 6-1, 2015, pp. 1-4. doi: $10.11648 /$ j.avs.s.2015030601.11

\begin{abstract}
This study was conducted in poultry farm in animal resources department, College of agriculture, Diyala University during period 112 to $1 \backslash 42015$ to determine the effect of adding different levels of date palm pollen in productive performance and some eggs quality of layer hens chicken by use of 156 hens of lohman brown 50 weeks age. The treatments was $0,6,8,10 \mathrm{gm} . \mathrm{kgm}$ diet (T1, T2, T3andT4) respectively. The results shows that there was a significant different $(\mathrm{p} \leq 0.01)$ in hen day production which was $84.59,82.39,81.53,77.37 \%$ for $\mathrm{T} 4, \mathrm{~T} 3, \mathrm{~T} 2, \mathrm{~T} 1$ respectively ,the cumulative eggs, eggs weight, eggs mass, feed conversation were have a significant different for $\mathrm{T} 4$ compared with experiment and control treatments. There was a significant decreased in body weight and feed consumption for T2, T3 and T4 compared with T1 (cont), there were no significant different in eggs quality except shell weight and thickness which have significant different for date palm pollen treatments.
\end{abstract}

Keywords: Date Palm Pollen, Hens, Egg Production

\section{Introduction}

The use of herbal medicine has become increasing worldwide and many ancient records of herbal medical plants Suspension of Phoenix dactylifera date palm pollen DPP is an herbal mixture that is widely used as a folkremedy for curing male infertility in traditional medicine ${ }^{1,2}$. It is a good source of natural antioxidants ${ }^{3}$. Flavonoid is the major class of phytoestrogen. It is functionally and structurally similar to estrogen ${ }^{4}$ that affects Spermatogenesis. Flavonoidsalso act as antioxidant ${ }^{5}$. Antioxidants can also protect testis ${ }^{6,7}$. This component also protects sperm and is associated with semen quality as well ${ }^{8}$. The use of DPP as feed additive to animal diet lead to more daily gain ${ }^{9}$ and the use of water extract of DPP record a significant different in production and weight of eggs compared to control group and in ovary tract weight $^{10}$.The DDP have estrogen hormone play a very important effect in gonads ${ }^{11,12}$. The fertility effects of DPP in traditional medicine are not supported by scientifically and the literature does show little reports on its effects on fertility. Therefore, the aim of this study is to determine the effects of DPP on the productive of layer hens lohman chicken .

\section{Materials and Methods}

The flock used in this experiment consist of 156 hens (average body weight 1990gm) lohman brown, 50 weeks of age and randomly divided into four groups for treatments practice, each group consist of 39 hens each group divided into three subgroup represent three replicates (13 hens for each replicate) the treatments referred as fallowing: T1 as control group (received standard diet without any additives), $\mathrm{T} 2, \mathrm{~T} 3$, and $\mathrm{T} 4$ represented additives of 6,8 and $10 \mathrm{gm}$ of date palm pollen $/ \mathrm{kg}$ diet . Hens were housed on floor pens $(150 \times 200 \mathrm{~cm})$. The diet used in this experiment as showed in Table1.The data were collected for production characteristics were: Percentage of hen day production (HD\%), egg weight, eggs mass, cumulative eggs production, feed consumption, feed conversion, body weight and for eggs quality 
characteristics were: shell thickness, shell weight, yolk height, Hugh unit, yolk weight, albumen weight, yolk index color. The experimental design for this experiment was Completely Randomized Design, each treatment with three replicates and the significance of differences between means detected by Duncan's Multiple Ranges test ${ }^{13}$, and the analysis of variance performed by used SPSS programe ${ }^{14}$.

Table 1. Diet composition and Calculated analysis.

\begin{tabular}{ll}
\hline Ingredient and analysis & $\mathbf{( \% )}$ \\
\hline Corn & 66.4 \\
Soybean meal (48\% CP) & 19.2 \\
Wheat & 6 \\
Dicalcium phosphate & 1.2 \\
Limestone & 6.1 \\
Mineral premix 1 & 0.05 \\
Vitamin premix 2 & 0.1 \\
Salt (NaCl) & 0.41 \\
Coccidiostat & 0.05 \\
D,L-Methionine & 0.07 \\
Selenium premix3 & 0.1 \\
Mold inhibitor & 0.05 \\
Lysine HCl & 0.05 \\
Choline chloride & 0.12 \\
Total & 100 \\
Calculated analysis & \\
Crude protein, (\%) & 16.03 \\
AME, (kcal/kg) & 2.918 \\
Lysine, (\%) & 0.82 \\
Methionine + cysteine, $\%)$ & 0.63 \\
Calcium, (\%) & 2.7 \\
Available phosphorus, $\%)$ & 0.42 \\
\hline
\end{tabular}

1 Mineral premix contained the following in milligrams per kilogram of diet: manganese, 120; zinc, 120; iron, 180; copper, 10; iodine, 2.5; Cobalt, 1.0 .

2 Vitamin premix contained the following per kilogram of diet: vitamin A, 13,200 IU; cholecalciferol, 4,000 IU; vitamin E, 66 IU; vitamin B12,

$34.6 \mathrm{ug}$; riboflavin, $13.2 \mathrm{mg}$; niacin, $110 \mathrm{mg}$; pantothenic acid, $22 \mathrm{mg}$; vitamin K, $4 \mathrm{mg}$; folic acid, $2.2 \mathrm{mg}$; thiamine, $4 \mathrm{mg}$; pyridoxine, $8 \mathrm{mg}$; And biotin, 252 ug.3Selenium premix contained sodium selenite $(\mathrm{Na} 2 \mathrm{SeO} 3)$, providing $0.3 \mathrm{mg} / \mathrm{kg}$.

4Data expressed on a percentage of dry matter basis. Formulations Confirmed by proximate analyses

\section{Results and Discussion}

The results in Table 2 showed there was a significant different $(p \leq 0.05)$ in HD production for DPP treatments compared with control and for all experiments period for $\mathrm{T} 4$ and for period 2,3,4 for T2 and T3 but in general means and that mean all DPP treatments have a significant differences compared with control group. This differences may be caused by increasing of FSH and LH hormones 15 because DPP have high concentration of estradiol and estrogen hormone10 and DPP have ability to increasing growth of ovary, ovary ducts and them functions and that caused in HD production increasing as seen in table2.

Table 2. Effect of DPP on percentage of hen day eggs production (HD \%).

\begin{tabular}{lllll}
\hline \multicolumn{1}{l}{ Treatment } & \multirow{2}{*}{ Teriod } & T2* & T3 & T4 \\
\cline { 1 - 4 } 1 & $76.81 \pm 1.45$ & $77.29 \pm 3.46$ & $79.75 \pm 2.84$ & $80.25 \pm 1.78$ \\
& $\mathrm{~B}$ & $\mathrm{~B}$ & $\mathrm{AB}$ & $\mathrm{A}$ \\
2 & $77.71 \pm 2.18$ & $81.29 \pm 1.11$ & $82.69 \pm 1.96$ & $82.43 \pm 2.28$ \\
& $\mathrm{C}$ & $\mathrm{B}$ & $\mathrm{B}$ & $\mathrm{A}$ \\
3 & $78.94 \pm 1.463$ & $82.02 \pm 3.77$ & $83.04 \pm 4.43$ & $85.12 \pm 1.93$ \\
& $\mathrm{C}$ & $\mathrm{B}$ & $\mathrm{B}$ & $\mathrm{A}$ \\
4 & $80.79 \pm 0.8$ & $84.66 \pm 2.61$ & $85.52 \pm 1.34$ & $87.44 \pm 0.39$ \\
\multirow{2}{*}{ General mean } & $\mathrm{C}$ & $\mathrm{B}$ & $\mathrm{B}$ & $\mathrm{A}$ \\
& $77.94 \pm 0.37$ & $81.74 \pm 1.53$ & $82.32 \pm 1.39$ & $84.91 \pm 0.59$ \\
\hline
\end{tabular}

* T1 control without any additive

*T2, T3and T4 feed with DPP 6,8and $10 \mathrm{gm} / \mathrm{kg}$ diet

* Means with different letters significantly different at $\mathrm{P}<0.05$.

Table 3 refers to a significant effect $(\mathrm{p} \leq 0.05)$ in cumulative eggs production (egg/layer) for all DPP treatments in general means and for all experiments period this result came by increasing hormones lead to high laying sequences10and that results in increasing in eggs laying number and seen especially in general mean and that increasing feed metabolic.

Table 3. Effect of DPP on cumulative eggs production (egg/layer).

\begin{tabular}{|c|c|c|c|c|}
\hline $\begin{array}{l}\text { Treatment } \\
\text { Period }\end{array}$ & T1* & $\mathbf{T} 2 *$ & T3 & T4 \\
\hline \multirow{2}{*}{1} & $10.20 \pm 0.60$ & $10.37 \pm 0.87$ & $10.99 \pm 0.23$ & $11.76 \pm 0.34$ \\
\hline & B & B & B & A \\
\hline \multirow{2}{*}{2} & $10.86 \pm 0.27$ & $11.04 \pm 0.33$ & $11.37 \pm 0.17$ & $12.14 \pm 0.14$ \\
\hline & $\mathrm{C}$ & B & B & A \\
\hline \multirow{2}{*}{3} & $10.39 \pm 0.70$ & $11.38 \pm 0.24$ & $11.21 \pm 0.77$ & $12.15 \pm 0.86$ \\
\hline & $\mathrm{C}$ & $\mathrm{BC}$ & B & A \\
\hline \multirow{2}{*}{4} & $11.12 \pm 0.19$ & $11.42 \pm 0.58$ & $11.40 \pm 0.94$ & $12.67 \pm 0.79$ \\
\hline & B & B & B & A \\
\hline \multirow{2}{*}{$\begin{array}{l}\text { General } \\
\text { mean }\end{array}$} & $10.13 \pm 0.84$ & $11.19 \pm 0.43$ & $11.16 \pm 0.62$ & $12.56 \pm 0.61$ \\
\hline & $\mathrm{C}$ & $\mathrm{B}$ & $\mathrm{B}$ & A \\
\hline
\end{tabular}

* T1 control without any additive

*T2, T3and T4 feed with DPP 6,8 and $10 \mathrm{gm} / \mathrm{kg}$ diet

* Means with different letters significantly different at $\mathrm{P}<0.05$.

Table 4. Effect of DPP on eggs weight production (gm).

\begin{tabular}{|c|c|c|c|c|}
\hline $\begin{array}{l}\text { Treatment } \\
\text { Period }\end{array}$ & T1* & T2* & T3 & T4 \\
\hline 1 & $66.83 \pm 1.22$ & $68.71 \pm 0.78$ & $67.84 \pm 1.27$ & $1.44 \pm 67.3$ \\
\hline 2 & $66.83 \pm 0.87$ & $67.34 \pm 0.59$ & $68.95 \pm 0.72$ & $69.96 \pm 0.56$ \\
\hline 3 & $\begin{array}{l}64.19 \pm 0.78 \\
C\end{array}$ & $\begin{array}{l}67.58 \pm 0.95 \\
B\end{array}$ & $70.38 \pm 0.94$ & $72.14 \pm 0.88$ \\
\hline 4 & $63.87 \pm 0.85$ & $70.92 \pm 0.57$ & $71.51 \pm 0.03$ & $72.44 \pm 0.14$ \\
\hline $\begin{array}{l}\text { General } \\
\text { mean }\end{array}$ & $\begin{array}{l}65.66 \pm 0.27 \\
C\end{array}$ & $\begin{array}{l}68.40 \pm 0.51 \\
\mathrm{BC}\end{array}$ & $\begin{array}{l}69.47 \pm 0.49 \\
\text { B }\end{array}$ & $\begin{array}{l}70.74 \pm 0.47 \\
\text { A }\end{array}$ \\
\hline
\end{tabular}

* T1 control without any additive

*T2, T3and T4 feed with DPP 6,8and $10 \mathrm{gm} / \mathrm{kg}$ diet

* Means with different letters significantly different at $\mathrm{P}<0.05$.

There were a significant effect $(p \leq 0.05)$ in eggs weight in Table 4 for all DPP treatments in third and fourth period and 
an general means that effect may be caused by increasing of estrogen effect on liver secretion of lipids proteins and the hormone caused increasing in growth of epithelium of ovary16.

In Table 5 there were a significant effect $(p \leq 0.05)$ in eggs mass for all DPP treatments in period 3and 4 as well as in general mean. These differences came from the increasing in eggs production. There was no significant effect in feed intake in all experiment period.

Table 5. Effect of DPP on eggs mass (gm egg/layer/day).

\begin{tabular}{|c|c|c|c|c|}
\hline Treatment & \multirow{2}{*}{ T1* } & \multirow{2}{*}{ T2* } & \multirow{2}{*}{ T3 } & \multirow{2}{*}{ T4 } \\
\hline Period & & & & \\
\hline \multirow{2}{*}{1} & $50.8 \pm 0.61$ & $52.11 \pm 2.78$ & $53.0 \pm 2.72$ & $58.2 \pm 2.56$ \\
\hline & B & $\mathrm{AB}$ & $\mathrm{AB}$ & A \\
\hline \multirow{2}{*}{2} & $51.66 \pm 1.13$ & $57.60 \pm 1.15$ & $56.21 \pm 1.98$ & $63.31 \pm 2.41$ \\
\hline & $\mathrm{C}$ & B & B & A \\
\hline \multirow{2}{*}{3} & $49.76 \pm 1.31$ & $54.63 \pm 2.04$ & $60.20 \pm 1.55$ & $66.80 \pm 0.95$ \\
\hline & $\mathrm{C}$ & $\mathrm{BC}$ & B & A \\
\hline \multirow{2}{*}{4} & $51.74 \pm 0.2$ & $58.11 \pm 2.38$ & $58.59 \pm 1.76$ & $65.18 \pm 1.91$ \\
\hline & $\mathrm{C}$ & B & B & A \\
\hline \multirow{2}{*}{$\begin{array}{l}\text { General } \\
\text { mean }\end{array}$} & $50.10 \pm 0.44$ & $55.01 \pm 1.47$ & $57.44 \pm 1.52$ & $63.44 \pm 1.71$ \\
\hline & $\mathrm{C}$ & B & B & A \\
\hline
\end{tabular}

* T1 control without any additive

*T2, T3and T4 feed with DPP 6,8and $10 \mathrm{gm} / \mathrm{kg}$ diet

* Means with different letters significantly different at $\mathrm{P}<0.05$.

Feed conversion in Table 6 showed a significant effect $(\mathrm{p} \leq$ 0.05 ) for all DPP treatments in period2, 3 and 4 as well as in general mean, that results came from increasing in eggs without increasing in feed intake 17 in Table 7 there was significant decreasing in body weight in all experiment period and for all DPP treatments, that result may cause by high production of eggs make body energy go for production mainly. Effect of treatments on eggs quality characteristics there were no significant effect $(\mathrm{p} \leq 0.05)$ except shell weight and thickness as seen in Table 8 and this result came from increasing in calcium observation and metabolic.

Table 6. Effect of DPP on feed conversation (gm. egg/gm. feed).

\begin{tabular}{|c|c|c|c|c|}
\hline Treatment & \multirow{2}{*}{ T1* } & \multirow{2}{*}{$T 2 *$} & \multirow{2}{*}{ T3 } & \multirow{2}{*}{ T4 } \\
\hline Period & & & & \\
\hline \multirow{2}{*}{1} & $2.20 \pm 0.05$ & $2.15 \pm 0.06$ & $2.20 \pm 0.08$ & $1.82 \pm 0.08$ \\
\hline & A & A & A & B \\
\hline \multirow{2}{*}{2} & $2.33 \pm 0.03$ & $2.06 \pm 0.04$ & $1.97 \pm 0.09$ & $1.82 \pm 0.08$ \\
\hline & A & B & $\mathrm{AB}$ & $\mathrm{C}$ \\
\hline \multirow{2}{*}{3} & $2.41 \pm 0.08$ & $2.10 \pm 0.08$ & $1.85 \pm 0.15$ & $1.73 \pm 0.03$ \\
\hline & A & B & $\mathrm{BC}$ & $\mathrm{C}$ \\
\hline \multirow{2}{*}{4} & $2.33 \pm 0.03$ & $2.05 \pm 0.07$ & $2.04 \pm 0.10$ & $1.74 \pm 0.08$ \\
\hline & A & B & B & $\mathrm{C}$ \\
\hline \multirow{2}{*}{$\begin{array}{l}\text { General } \\
\text { mean }\end{array}$} & $2.32 \pm 0.04$ & $2.10 \pm 0.03$ & $2.02 \pm 0.12$ & $1.78 \pm 0.04$ \\
\hline & A & B & B & $\mathrm{C}$ \\
\hline
\end{tabular}

* T1 control without any additive

*T2, T3and T4 feed with DPP 6,8and $10 \mathrm{gm} / \mathrm{kg}$ diet

* Means with different letters significantly different at $\mathrm{P}<0.05$.
Table 7. Effect of DPP on body weight (gm).

\begin{tabular}{|c|c|c|c|c|}
\hline $\begin{array}{l}\text { Treatment } \\
\text { Period }\end{array}$ & T1* & T2* & T3 & T4 \\
\hline 1 & $66.83 \pm 1.22$ & $68.71 \pm 0.78$ & $0.84 \pm 67.27$ & $1.44 \pm 67.3$ \\
\hline 2 & $66.83 \pm 0.87$ & $67.34 \pm 0.59$ & $68.95 \pm 0.72$ & $69.96 \pm 0.56$ \\
\hline \multirow{2}{*}{3} & $64.19 \pm 0.78$ & $67.58 \pm 0.95$ & $70.38 \pm 0.94$ & $72.14 \pm 0.88$ \\
\hline & $\mathrm{C}$ & B & A & A \\
\hline \multirow{2}{*}{4} & $63.87 \pm 0.85$ & $70.92 \pm 0.57$ & $71.51 \pm 0.03$ & $72.44 \pm 0.14$ \\
\hline & $\mathrm{B}$ & A & A & A \\
\hline \multirow{2}{*}{$\begin{array}{l}\text { General } \\
\text { mean }\end{array}$} & $65.66 \pm 0.27$ & $68.40 \pm 0.51$ & $69.47 \pm 0.49$ & $70.74 \pm 0.47$ \\
\hline & $\mathrm{C}$ & $\mathrm{BC}$ & B & A \\
\hline
\end{tabular}

* T1 control without any additive

*T2, T3and T4 feed with DPP 6,8and $10 \mathrm{gm} / \mathrm{kg}$ diet

* Means with different letters significantly different at $\mathrm{P}<0.05$.

Table 8. Effect of DPP on eggs quality traits.

\begin{tabular}{lllll}
\cline { 1 - 4 } Treatment & \multirow{2}{*}{ T1* } & T2* & T3 & T4 \\
\cline { 1 - 4 } Character & & & & \\
Shell weight & $5.61 \pm 0.22$ & $6.55 \pm 0.39$ & $6.84 \pm 0.27$ & $6.87 \pm 0.33$ \\
& B & A & A & A \\
gm Shell & $0.31 \pm 0.01$ & $0.33 \pm 0.01$ & $0.34 \pm 0.01$ & $0.34 \pm 0.01$ \\
thickness & B & A & A & A \\
& $5.19 \pm 0.78$ & $67.58 \pm 0.95$ & $70.38 \pm 0.94$ & $72.14 \pm 0.88$ \\
& C & B & A & A \\
\hline
\end{tabular}

* T1 control without any additive

*T2, T3and T4 feed with DPP 6,8and $10 \mathrm{gm} / \mathrm{kg}$ diet

* Means with different letters significantly different at $\mathrm{P}<0.05$.

\section{Conclusion}

From the results of research which refer to that DPP have a significant effects in all characteristics included in the study, beside there was no side effect seen on chicken health or eggs quality therefore we conclusion that adding DPP in this concentration have a good benefits without any effects on human health and we can used it in this concentration safely.

\section{References}

[1] Aboua YG, du Plessis SS, Reichgelt P, and Brooks N.2009. The invitro effects of superoxide, some commercially available antioxidants and red palm oil on sperm motility. Asian J Androl. 11:695-702.

[2] Bahmanpour S, talaei T, Vojdani Z, Panjehshahin MR, Poostpasan A, Zareei S. 2006. effect of Phoenix Dactylifera pollenon sperm parameters and reproductive system of adult male rats. Iranian Journal of medical sciences. 2006, 31: 208212.

[3] Al-Farsi M, Alasalvar C, Morris A, Baron M, Shahidi F. 2005.Comparison of antioxidant activity, anthocyanins, carotenoids, and phenolics of three native fresh and sun-dried date (Phoenix dactylifera L.) varieties grown in Oman. J Agric Food Chem. 2005; 53:7592-9.

[4] Breithofer A, Graumann K, Scicchitano MS, Karathanasis, SK, Butt TR, Jungbauer A.1998. Regulation of human estrogen receptor by phytoestrogens in yeast and human cells. J Steroid Biochem Molec Biol.; 67: 421-429. 
[5] Lotito SB, Frei B.2006. Consumption of flavonoid-rich foods andincreased plasma antioxidant capacity in humans: cause, consequence, or epiphenomenon? Free Radic Biol Med.; 41:1727-46.

[6] Guo H, An C, Gan Z, Mai E, Xing S, Chen R.2004. Experimental study on antioxidant and calcium channel blockade preventing testicular fibrosis in rats. Zhonghua Nan Ke Xue.; 10:857-63.

[7] Aydilek N, Aksakal M, Karakilcik AZ.2004. Effects of testosterone and vitamin $\mathrm{E}$ on the antioxidant system in rabbit testis.Andrologia; 36:277-81.

[8] Shiva M, Gautam AK, Verma Y, Shivgotra V, Doshi H, Kumar S.2011.Association between sperm quality, oxidative stress, and seminal antioxidant activity. Clin Biochem.; 44:319-24.

[9] Al-Qarawi A. A. ,Mousa H. M., Ali B. E., Abdel-Rahman H. and El -Mougy S. A.2004. Protective effect of extracts from dates (.Phoenix dactylifera L.) on carbon tetrachlorideInduced Hepatotoxicity in rats. Intern. J. APPL. Res. Vet. Med. Vol. 2, No. 3 .

[10] ARHAEM S.H.2004. Effects of use different level from water extract of DATE PALM POLLEN on ovary function and some production CHARACTERISTICS. Al-furat Agriculture Science 6(1):98-103.
[11] Hess R. A., Gist D. H, Bunich D., Lubahn D. B., Farrell A., Bahr J., Cook P. S. and Green G. L. 1997.Estrogen receptor (a and $\mathrm{P}$ ) expression in the excurrent ducts of the adult male rat reproductive tract. J. Andro., 18:602-611.

[12] Duncan, D. D.1955. Multiple range and Multiple F-Test .Bio metrics . 11:1-42.

[13] SPSS, 2003. SPSS For Windows Release 10.0, SPSS Inc.

[14] Liu, H.K , Long ,D.W ; Bacon , W . L 2001.Preovulatory luteinizing hormone surge intervallic Andyoung laying turkey hens early in the egg production period.poult.Sci.80: 13641370 .

[15] Walzem, .L.; Harson ,R.J; Williams ,D.L and Hamilton , R.L .1999.Estrogen Induction of VLDL assembly in egg laying hens.J.Nut.129:467-472.

[16] Ahmed M. B., Hasona N. A. S. and Selemain H.2008. Protective effects of extract from dates (Phoenix dactylifera L.) and. ascorbic acide on thio actamide -induced hepatotoxicity in rats; Iranian J. Pharma. Resar, 7(3): 193- 201. 